\title{
NOTES
}

\section{JUDICIAL REVIEW OF INFORMAL ADMINISTRATIVE RULEMAKING}

In the last few weeks of its 1982 term, the Supreme Court of the United States handed down a decision that will have a major impact on administrative law. In Motor Vehicles Manufacturers Association v. State Farm Mutual Automobile Insurance Co. ${ }^{1}$ commonly known as the "air bag" case, the Supreme Court apparently reconfirmed the propriety of federal courts taking a "hard look" at agencies' informal promulgation and rescission of rules.

Informal rulemaking today plays a major role in the administrative process. "[T]he crush of increased responsibilities and the burdens of trial-type hearings have led . . . federal agencies to turn from case-by-case adjudication to general rulemaking proceedings in order to develop administrative policy."2 Congress and the courts liave recognized the utility of informal rulemaking and have provided that in many instances agencies should be free to make rules witlout the strictures of the formal liearing process. ${ }^{3}$ In the past, courts seldom intruded upon inforinal rulemaking and when they did intrude, they did so with great deference to agency findings. ${ }^{4}$ But a different trend has recently emerged: "widespread recognition that agencies exercise broad lawmaking discretion, togetleer with mounting distrust of the

1. 103 S. Ct. 2856 (1983).

2. Stewart, Vermont Yankee and the Evolution of Administrative Procedure, 91 HARv. L. REv. 1805, 1811 (1978); see, e.g., Note, The Use of Generic Rulemaking to Resolve Environmental Issues in Nuclear Power Plant Licensing, 61 VA. L. REv. 869 (1975).

3. See United States v. Florida E.C. Ry., 410 U.S. 224 (1973)(clear expression of congressional intent to require formal rulemaking necessary before courts should restrain agencies froin using informal procedures); see also infra notes 17-28 and accompanying text.

4. See Delong, Informal Rulemaking and the Integration of Law and Policy, 65 VA. L. REv. 257, 276 \& n.111 (1979); K. Davis, Administrative LaW of THE Seventies \& 29.01-1, at 655 (1976)(commenting that his four volume treatise in 1958 cited only four cases of judicial review of informal rulenaking); see, e.g., Pacific States Box \& Basket Co. v. White, 296 U.S. 176 (1935). One reason for this lack of judicial activity was that only in the past few decades have administrative agencies actively used their rulemaking powers. As Professors Gellhorn and Robinson note in Rulemaking "Due Process": An Inconclusive Dialogue, 48 U. CH1. L. REv. 201, 203 (1981), it was not until 1956, in United States v. Storer Broadcasting Co., 351 U.S. 192 (1956), that the Supreme Court confirmed the authority of an agency to use rulemaking to determine issues of agency policy. 
wisdom and fairness of agency decisionmaking, have led courts to exercise more exacting scrutimy of the factual and analytical bases of such decisions." 5

Yet the propriety of and the limits to judicial scrutiny of informal administrative rulemaking are by no means clear. Section 706(2)(A) of the Administrative Procedure Act (APA) 6 prescribes the "arbitrary and capricious" test as the basic standard of review of mformal rulemaking. In several cases smce 1971, the Supreme Court has attenipted to interpret the meaning of Congress's rather vague guidelines for judicial review. State Farm is the latest in a line of cases that begins with Citizens to Preserve Overton Park, Inc. v. Volpe ${ }^{7}$ and continues with Vermont Yankee Nuclear Power Corp. v. Natural Resources Defense Council, Inc. ${ }^{8}$ in which the Court has sought to define an acceptable standard of review of informal agency action. Each of these cases contributes to the definition of the proper role of the federal courts in reviewing administrative action. None, however, completely clarifies the issue.

This note discusses the questions left unresolved by the early Supreme Court decisions ${ }^{9}$ and analyzes how the lower courts and commentators have responded to the Court's ambiguous directives, especially those contamed in Vermont Yankee. ${ }^{10}$ It then describes the holding and background of State Farm ${ }^{11}$ and comments on the case's implications for administrative law. ${ }^{12}$

\section{INFORMAL RULEMAKING AND JUdiCIAL REVIEW}

If its enabling statute so indicates, an agency may estabhish policies through either adjudication or rulemaking. ${ }^{13}$ The APA specifies the procedures for formal adjudication, ${ }^{14}$ formal ruleınaking, ${ }^{15}$ and infor-

5. Stewart, supra note 2, at 1811; see also Delong, supra note 4, at 277-82; McGowan, Reflections on Rulemaking Review, 53 Tul. L. REv. 681 (1979).

6. 5 U.S.C. $\$ 706(2)(A)(1982)$.

7. 401 U.S. 402 (1971).

8. 435 U.S. 519 (1978). These cases are discussed infra at text accompanying notcs 25-59.

9. See infra notes $44-48$ and accompanying text.

10. See infra notes $60-82$ and accompanying text.

11. See infra notes 83-146 and accompanying text.

12. See infra notes 147-71 and accompanying text.

13. See NLRB v. Bell Aerospace Co., 416 U.S. 267, 294 (1974); SEC v. Chenery Corp., 332 U.S. 194, 201-03 (1947); National Petroleum Refiners Ass'n v. FTC, 482 F.2d 672, 692-98 (D.C. Cir. 1973)(reversing lower court's determination that FTC Act did not authorize substantive rulemaking), cert. denied, 415 U.S. 951 (1974).

14. 5 U.S.C. $\$ \S 554,556,557$ (1982).

15. 5 U.S.C. $\$ \$ 553,556,557$ (1982). 
mal rulemaking. ${ }^{16}$ Many agencies have largely abandoned the use of formal proceedings and have increasingly coine to rely on infornal or "notice and comment" rulemaking to accomplish congressional objectives. ${ }^{17}$

The APA requires only minimal procedures for informal ruleinaking. ${ }^{18}$ Once an agency develops a proposed rule, it inust publish a notice of the proposed rulemaking in the Federal Register. ${ }^{19}$ Interested persons then have the opportunity to comment on the proposed rule in writing by submitting data, views, or argunient. Agencies also may, at their discretion, allow oral presentations. ${ }^{20}$ After considermg the relevant comments and other inaterials, if the agency decides to go ahead with the rule, it must provide a concise statement of basis and purpose to accoinpany the final rules. ${ }^{21}$ The final rule niay differ from the proposed rule if the agency provided adequate notice of the general subject to potential participants. ${ }^{22}$ In contrast to the trial-type procedures required for formal adjudication and formal rulemaking, the procedures that agencies einploy in informal rulemaking are niore like those used by a legislative body. ${ }^{23}$

\section{A. Overton Park: The Evolving Scope of Judicial Review of Informal Agency Action.}

Congress did not specify in the APA the precise standard appropriate for judicial review of informal rulemaking. Instead it simply

16. 5 U.S.C. $§ 553$ (1982).

17. See generally K. Davis, Administrative Law of the Seventies 167-69 (1976); Shapiro, The Choice of Rulemaking or Adjudication in the Development of Administrative Policy, 78 HARv. L. Rev. 921 (1965).

18. See, e.g., Delong, supra note 4 , at 258-60.

19. 5 U.S.C. \& 553(b) (1982). The notice must give the time, place, and nature of the proceedings, the legal authority under which the rule is proposed, and either the substance of the proposed rule or a description of the issues involved. The courts have elaborated on the necessary content of the notice. See Portland Cement Ass'n v. Ruckelshaus, 486 F.2d 375, 393-95 (D.C. Cir. 1973), cert. denied, 417 U.S. 921 (1974); Mobil Oil Corp. v. FPC, 483 F.2d 1238, 1251-63 (D.C. Cir. 1973). See generally K. DAVIs, supra note 17, at 172.

20. 5 U.S.C. \& 553 (c) (1982).

21. Id. This statement must indicate the issues considered by the agency and the agency's disposition of those issues. Portland Cement Ass'n v. Ruckelshaus, 486 F.2d 375, 393-95 (D.C. Cir. 1973), cert. denied, 417 U.S. 921 (1974).

22. See Ethyl Corp. v. EPA, 541 F.2d 1, 48 (D.C. Cir.)(en banc), cert. denied, 426 U.S. 941 (1976); California Citizens Board Ass'n v. Uniled States, 375 F.2d 43, 48-49 (9th Cir.), cert. denied, 389 U.S. 844 (1967).

23. The APA contains no explicit procedures for informal adjudication, so if an adjudication is not "required by statute to be determined on the record after opportunity for an agency hearing," 5 U.S.C. $\$ 554$ (a) (1982), or required by the due process clause to be on the record, see Wong Yang Sung v. McGrath, 339 U.S. 33, 50-51 (1950), the applicable procedures are those specified by statute or provided in the agency's discretion. 
provided one section dealing with the "scope of review."24 In 5 U.S.C. $\S 706$, Congress instructed the courts to set aside agency action that fails to meet certain standards. Courts apply different standards under the statute's hierarchy depending on the type of agency action being reviewed. Courts conduct their inost intrusive review when they examine certain types of agency findings "de novo"; 25 they review "formal" agency actions under the soinewhat less vigorous "substantial evidence" standard.26 Courts review all other agency actions that are subject to review under the arbitrary and capricious test ${ }^{27}$ and several other statutory criteria designed to ensure that the agency observed proper procedures and did not act ultra vires or in violation of the Constitution. ${ }^{28}$

Although courts usually have little difficulty deciding which of the APA's standards to apply in a given case, they frequently disagree as to what a particular standard means. Thus, courts seein to apply varying scopes of review even though they are applying the same statutory standard of review. For inany years, both before and after the APA was enacted, courts reviewed informal agency ruleinaking by considering only whether the agency had a rational basis for the disputed rule and whether the agency liad statutory authority to promulgate the rule. ${ }^{29}$ In practice, sucli review proved even inore deferential than the current arbitrary and capricious standard.

In the 1970's, the Supreine Court addressed the scope of review question in two inajor decisions. The first, Citizens to Preserve Overton Park, Inc. v. Volpe, ${ }^{30}$ dealt specifically with inforinal adjudications, but the Court's language applies to inforinal ruleinaking as well. ${ }^{31}$ In Over-

24. The primary questions that this section raises in informal rulemaking are whether the "substantial evidence" standard or the arbitrary and capricious test apphes to informal actions, and the inore difficult question of what is meant by those standards.

25. K. Davis, Administrative Law Treatise $\$ 29.00-1$ (1982 Supp.).

26. Id.

27. Abbott Laboratories v. Gardner, 387 U.S. 136, 143 (1967)(the substantial evidence test provides for "considerably more generous judicial review than the 'arbitrary and capricious' test").

28. See 5 U.S.C. $\$ 706(2)(B)-(D)$ (1982).

29. See, e.g., United States v. George S. Bush \& Co., 310 U.S. 371 (1940); Superior Oil Co. v. FPC, 322 F.2d 601 (9th Cir. 1963), cert. denied, 377 U.S. 922 (1964).

30. 401 U.S. 402 (1971).

31. The Court also decided Camp v. Pitts two years after Overton Park. In Camp, 411 U.S. 138 (1973)(per curiam), the Court reiterated that the appropriate standard of review was the arbitrary and capricious test. The per curiain opinion stated that courts were not free to hold de novo hearings when a "contemporaneous explanation of the ageucy decision" was available. 411 U.S. at 142-43. In applying the arbitrary and capricious standard, "the focal point for judicial review should be the administrative record already in existence [and the vahitity of the agency's] action must, therefore, stand or fall on the propriety of that finding." Id. In Camp, the "conteinporaneous explanation" was a single letter to the apphicant. Although it did not clarify the standard, 
ton Park the Court held that the appropriate standard of review of informal actions was the "arbitrary and capricious" test of section $706(2)(A)$ of the Administrative Procedure Act.

To make this finding the court inust consider whether the decision was based on a consideration of the relevant factors and whether there has been a clear error of judgment. . . . Although this inquiry into the facts is to be searching and careful, the ultimate standard of review is a narrow one. The court is not empowered to substitute its judgment for that of the agency. ${ }^{32}$

But the Overton Park Court did remand the case to the lower court for a "thorough, probing, in-depth review" of the administrative record that was the basis for the Secretary of Transportation's decision. ${ }^{33}$ By requirmg a "hard look" at the administrative record, the Court specified that the arbitrary and capricious test should apply, but equated that standard with the "clear error of judgment" or "clearly erroneous" standard. 34 Instead of seeking a mere "rational basis" for agency actions, the Supreme Court mandated that courts examine the agency record, and that agencies build a record to facilitate such review. In so doing, the Court "revolutionized the concept of judicial review of informal action." 35

Lower federal courts responded to the "somewhat Delphic opinion"36 in Overton Park in a number of ways. ${ }^{37}$ First, inany courts attempted to elaborate the implications of the arbitrary and capricious standard and to distinguisl it from the "substantial evidence" test."38 Although some federal appellate courts have perceived a distinction between the two standards, ${ }^{39}$ other courts of appeals concluded that the

Camp did make clear that the standard to be applied was the arbitrary and capricious test and that judicial review under that standard was to be based on the administrative record, not on evidence adduced at a judicial trial. See id. at 141-43.

32. Overton Park, 401 U.S. at 416 (citations omitted).

33. Id. The Court noted that "the Secretary's decision is entitled to a presumption of regularity." Id. at 415 .

34. K. Davis, supra note 25 , at $\$ 29.00$ (1982 Supp.).

35. Verkuil, Judicial Review of Informal Rulemaking: Waiting for Vermont Yankee I1, 55 TUL. L. REV. 418, 422 (1981).

36. Action for Children's Television v. FCC, 564 F.2d 458, 476 (D.C. Cir. 1977).

37. See McMillan \& Peterson, The Permissible Scope of Hearings, Discovery, and Additional Factfinding During Judicial Review of Informal Agency Action, 1982 DUKE L.J. 333.

38. The Supreme Court has defined substantial evidence as "such relevant evidence as a reasonable mind might accept as adequate to support a conclusion." Consolidated Edison Co. v. NLRB, 305 U.S. 197, 229 (1938); see also L. JAFFE, Judicial CoNTrol of AdMINISTRATIVE Acrion 596 (1965)("for reasonable mind we must substitute reasoning mind").

39. On different occasions courts of appeals have called the arbitrary and capricious standard an undemanding one, Ethyl Corp. v. EPA, 541 F.2d 1, 34 n.74 (D.C. Cir.)(en banc), cert. denied, 426 U.S. 941 (1976), and "the far less demanding one," Action for Children's Television v. FCC, 564 F.2d 458, 478 (D.C. Cir. 1977), in comparison to the "possibly stricter standard" of substantial evidence, Automobile Club of New York, Inc. v. Cox, 592 F.2d 658, 664 (2d Cir. 1979). See also 
distinction is largely semantic. ${ }^{40}$ Judge J. Skelly Wright notes an "emerging consensus of the Courts of Appeals that the distinction between the arbitrary and capricious standard and substantial evidence review is largely semantic, and that in the review of rules of general apphicability made after notice and comment rulemaking, the two criteria [do] tend to converge." "41

No matter what their views on the distinction between the two criteria, most courts of appeals construed the arbitrary and capricious standard as one that requires the courts to take a "hard look" at the agency decision. ${ }^{42}$ The lower courts interpreted the Supreme Court's comments in Overton Park, that review of the agency record on appeal

Judge J. Skelly Wright's views expressed in The Courts and the Rulemaking Process: The Limits of Judicial Review, 59 CORNELl L. REv. 375, 391 (1974): "The reviewing court [under the arbitrary and capricious standard] is not even authorized to examine whether a rulemaker's empirical conclusions have support in substantial evidence."

40. Judges on the United States Court of Appeals for the Second Circuit state: "While we still have a feeling that there may be cases where an adjudicative determination not supported by substantial evidence ... . would not be regarded as arbitrary or capricious, . . in the review of rules of general applicability made after notice and comment rulemaking, the two criteria do tend to converge," Associated Indus. v. United States Dep't of Labor, 487 F.2d 342, 349-50 (2d Cir. 1973)(Friendly, J.); and "[W] hen an agency engages in substantive rule-making, it abuses its discretion (or acts arbitrarily and capriciously) if its actions are not supported by substantial evidence." National Nutritional Foods Ass'n v. Weimberger, 512 F.2d 688, 705 (2d Cir. 1975)(Lumbard, J., concurring in the result).

Justice Frankfurter recognized this issue three decades ago: "Want of certainty in judicial review . . partly reflects the intractability of any formula to furnish definitions of content for all the impalpable factors involved in judicial review." Universal Camera Corp. v. NLRB, 340 U.S. 474, 477 (1951). See generally K. DAvis, supra note 25, at $\$ 29.00-1$; K. DAvis, supra note 4, at $\$ 29.00$; Friendly, Some Kind of Hearing, 123 U. PA. L. Rev. 1267, 1313 (1975). Justice Linde of the Arizona Supreme Court states:

Existing statutory and judicial formulations for reviewing the exercise of discretion are among the most unsatisfactory in the area of judicial review of agency action. Words such as "arbitrary," "capricious," or "abuse of discretion," state conclusions, not premises from which a conclusion may be derived. When a statute or a line of precedents instructs a reviewing court to set aside action found to be arbitrary, capricious, or an abuse of discretion, it merely provides the terms in which the conclusion of invalidity may be pronounced. These terms do nothing to articulate the process of analysis by which the issue of invalidity is to be litigated and decided.

Brodie \& Linde, State Court Review of Administrative Action: Prescribing the Scope of Review, 1977 ARIZ. ST. L.J. 537, 550.

41. Pacific Legal Found. v. DOT, 593 F.2d 1338, 1343 n.35 (D.C. Cir.) (quoting Associated Indus. v. United States Dep't of Labor, 487 F.2d 342, 349-50 (2d Cir. 1973)), cert. denied, 444 U.S. 830 (1979).

42. The "hard look" concept is usually traced back to Judge Harold Leventhal's opinion in Greater Boston Television Corp. v. FCC, 444 F.2d 841, 851 (D.C. Cir. 1970), cerl. dented, 403 U.S. 923 (1971): "Its supervisory function calls on the court to intervene . . . if the court becomes aware . . . that the agency has not really taken a 'hard look' at the salient problems, and has not genuinely engaged in reasoned decision-making." See Portland Cement Ass'n v. Ruckelshaus, 486 F.2d at 394 ("a continuing duty to take a 'laard look' "); see also Kleppe v. Sierra Club, 427 U.S. 390, 410 n.21 (1976)(courts must ensure agency has taken "hard look"). 
should be "thorough, probing, in-depth," 43 as requiring close scrutiny of agency decisionmaking. After Overton Park, the courts of appeals embarked on a course of rigorous review that dennanded a complete agency record and reasoned agency decisionmaking. ${ }^{44}$

Courts demanded a complete record from the agency because of the Supreme Court's directive in both Overton Park ${ }^{45}$ and Camp $v$. Pitts $^{46}$ that judicial review should be based almost entirely on the administrative record. The requirement of reasoned decisionmaking, including an articulation by the agency of its response to criticism and contrary evidence, when linked to courts' threats to remand to the agency, had the effect of inducing the agencies to institute more elaborate procedures so that the record demonstrated a "thorough ventilation of the issues." 47 The courts of appeals" actions effectively reformed the structure of informal rulemaking by engrafting formal procedures and created a "hybrid rulemaking" process. ${ }^{48}$ The result of these imposed procedures was a "paper hearing"-a midpoint on the contimuuin between informal notice and comment rulemaking and formal trial-type procedures.

43. 401 U.S. at 415; see, e.g., Pacific Legal Found. v. DOT, 593 F.2d 1338, 1343 (D.C. Cir.), cert. denied, 444 U.S. 830 (1979).

44. Professor Rodgers suggests that there are three essential ingredients of the hard look doctrine:

First is the substantive component, under which the courts read closely the operative statute to make sure the agencies stay within the scope of discretion assigned by Congress. Second is the procedural component, under which the courts have assumed a power to oversee the faimess of agency decisionmaking. . . .

Third, and most important, is the incessant dernand of the hard look case law for reasoned decisionmaking. . . . Under the doctrine, assumptions must be spelled out, imconsistencies explained, methodologies disclosed, contradictory evidence rebutted, record references solidly grounded, guesswork ehminated and conclusions supported in a

"manner capable of judicial understanding."

Rodgers, A Hard Look at Vermont Yankee: Environmental Law Under Close Scrutiny, 67 GEo. L.J. 699, 705-06 (1979)(footnote omitted)(quoting E. I. duPont de Nemours \& Co. v. Tram, 541

F.2d 1018, 1038 (4th Cir. 1976), aff'd in part and rev'd in part, 430 U.S. 112 (1977)).

45. 401 U.S. at 415.

46. 411 U.S. 138, 140 (1973)(per curiain).

47. Natural Resources Defense Council, Inc. v. NRC, 547 F.2d 633, 644 (D.C. Cir. 1976), rev'd sub nom. Vermont Yankee Nuclear Power Corp. v. Natural Resources Defense Council, Inc., 435 U.S. 519 (1978); see Stewart, The Development of Administrative and Quasi-Constitutional Law in Judicial Review of Environmental Decisionmaking: Lessons from the Clean Air Act, 62 IowA L. REv. 713 (1977).

48. For discussions of hybrid rulemaking and relevant cases, see DeLong, supra note 4, at 260 n.22; Nathanson, Probing the Mind of the Administrator: Hearing Variations and Standards of Judicial Review Under the Administrative Procedure Act and Other Federal Statutes, 75 ColuM. L. Rev. 721 (1975); Stewart, supra note 2; Williams, Hybrid Rulemaking Under the Administrative Procedure Act: A Legal and Empirical Analysis, 42 U. CHI. L. REv. 401 (1975); Note, The Judicial Role in Defining Procedural Requirements for Agency Rulemaking, 87 HARv. L. REv. 782 (1974). 


\section{B. Vermont Yankee: Restraining Judicial Review of Informal Agency Actions.}

The Supreme Court decided the second major scope of review case, Vermont Yankee Nuclear Power Corp. v. Natural Resources Defense Council, Inc., in 1978. In Vermont Yankee the Court tempered the lower courts' eagerness to inpose new procedural requirements upon the agencies in informal actions. The unanimous Court ${ }^{49}$ reversed the Umited States Court of Appeals for the District of Columbia Circuit which, the Supreme Court concluded, had rested its decision ${ }^{50}$ remanding an order granting an operating license on the "inadequacy of the procedures employed in the procedings." 51 The Court held that to impose "hybrid" rulemaking procedures was wrong-absent constitutional constraints or extremely compelling circumstances "the administrative agencies should be free to fashion their own rules of procedure and to pursue methods of inquiry capable of permitting them to discharge their inultitudinous duties." 52 The Court rejected the contention that the APA merely establishes minimum procedures that a court may supplement when issues of "Great Public Import" are involved.53 The Court said that the legislative history of the APA as well as policy considerations militated agamst such judicial requirement of extra procedural devices. ${ }^{54}$ The Court remanded the case so that the Court of

49. Justices Blackmun and Powell took no part in the decision. 435 U.S. at 558.

50. Natural Resources Defenses Council, Inc., v. NRC, 547 F.2d 633 (D.C. Cir. 1976).

51. 435 U.S. at 539.

52. Id. at 543 (quoting FCC v. Schreiber, 381 U.S. 279, 290 (1965)); see also FCC v. Pottsville

Broadcasting Co., 309 U.S. 134, 143 (1940).

53. Vermont Yankee, 435 U.S. at 545.

54. Id. at 546-48.

Congress intended that the discretion of the agencies and not that of the courts be exercised .. . . There are compelling reasons for construing [the APA] in this manner[:] In the first place, if courts continually review agency proceedings to deterinime whether the agency employed procedures which were, in the court's opinion, perfectly tailored to reach what the court perceives to be the "best" or "correct" result, judicial review would be totally unpredictable. And the agencies, operating under this vague injunction to employ the "best" procedures and facing the threat of reversal if they did not, would undoubtedly adopt full adjudicatory procedures in every instance. . . .

Secondly, it is obvious that the court in these cases reviewed the agency's choice of procedures on the basis of the record actually produced at the hearing, and not on the basis of the information available to the agency when it made the decision to structure the proceedings in a certain way. This sort of Monday morning quarterbacking not only encourages but almost compels the agency to conduct all rulemaking proceedings with the full panoply of procedural devices normally associated only with adjudicatory hearings.

Finally, and perhaps most importantly, this sort of review fundamentally misconceives the nature of the standard for judicial review of an agency rule. The court below uncritically assumed that additional procedures will automatically result in a more adequate record because it will give imterested parties more of an opportunity to participate and contribute to the proceedings. But inforinal rulemaking need not be based solely on the transcript of a hearing held before an agency. . . . In sum, this sort of unwarranted 
Appeals could determine whether the agency record was sufficient to uphold the agency's decision. ${ }^{5 s}$

Courts and commentators ${ }^{56}$ exhibited a mixed reaction to the $\mathrm{Ver}$ mont Yankee decision. Some commentators applauded the Court's reprimand to the lower courts for going beyond statutorily mandated procedures and changing informal rulemaking into a cumbersome, formalized process. ${ }^{57}$ Many commentators, however, were highly critical of the Court's attempt to stop the development of the administrative "common law," and charged that Vermont Yankee misinterpreted the APA and its legislative history and ignored the reahties of the administrative process. ${ }^{58}$ Some courts interpreted Vermont Yankee to require a highly deferential approach to review of agency action while others seemed to prove prescient the idea advanced by Justice Stewart that Vermont Yankee "might have the salutary side effect of leading reviewing courts to engage in more open and explicit scrutiny of substantive agency pohcies, rather than resortimg to indirect procedural devices."s9

One of the best examples of the deference prompted by Vermont Yankee can be seen in Connecticut Light \& Power Co. v. NRC, a 1982 decision of a panel of the United States Court of Appeals for the District of Columbia Circuit. ${ }^{60}$ The Nuclear Regulatory Commission

judicial examination of perceived procedural shortcomings of a rulennaking proceeding can do nothing but seriously interfere with that process prescribed by Congress.

Id. (emphasis in original).

55. Id. at 549.

56. See generally Barr, Judicial Review of Informal Rulemaking Procedure: When May Something More Formal be Required?, 27 AM. U.L. Rev. 781 (1978); Breyer, Vermont Yankee and the Courts' Role in the Nuclear Energy Controversy, 91 HARv. L. REv. 1833 (1978); Byse, Vermont Yankee and the Evolution of Administrative Procedure: A Somewhat Different View, 91 HARv. L. Rev. 1823 (1978); Davis, Administrative Common Law and the Vermont Yankee Opinion, 1980 UtAH L. Rev. 3; McGowan, supra note 5; Nathanson, The Vermont Yankee Nuclear Power Opinion: A Masterpiece of Statutory Misimterpretation, 16 SAN DIEGO L. REv. 183 (1979); Rodgers, supra note 44; Scaha, Vermont Yankee, the APA, the D.C. Circuit Court, and the Supreme Court, 1978 Sup. CT. Rev. 345; Stewart, supra note 2; Verkuil, supra note 35; Comment, Counter Revolution in the Federal Courts of Appeals-The Aftermath of Vermont Yankee, 15 U. RICH. L. REv. 723 (1981).

57. See, e.g., Byse, supra note 56; Breyer, supra note 56. But see Verkuil, supra note 35, at 419 ("If the Court is serious about preserving the outcome of Vermont Yankee, it inust add to its procedural decision a substantial one, modifying the expansive scope of review standard that allows reviewing courts to build a record in informal proceedings. If the Court fails to add a second decision to Vermont Yankee, it will have done very little to establish the primacy of agency control over the rulemaking process.").

58. See, e.g., Davis, supra note 56; Nathanson, supra note 56. Several commentators suggested that the impact of the decision would be minimal or, indeed, would be to increase judicial scrutiny of substantive matters. See Davis, supra note 56, at 15-17; Stewart, supra note 2, at 182022; see also K. DAvis, supra note 25, at 29.00-2 (Supp. 1982).

59. Stewart, supra note 2, at 1821 .

60. 673 F.2d 525 (D.C. Cir. 1982), cert. denied, 103 S. Ct. 79 (1983). 
(NRC) promulgated a rule mandating a stringent fire protection program for nuclear power plants under its undisputed authority to engage in notice and comment rulemaking to set safety standards. ${ }^{61}$ Connecticut Light and Power, a company licensed by the Commission to operate nuclear generatimg plants, objected botli to the procedures that the NRC utilized in adopting the rule and to the substance of the rules. ${ }^{62}$ The court of appeals upheld the NRC's decision, but did so reluctantly. ${ }^{63}$ Although highly deferential to the NRC's substantive determination, the court was less than satisfied with the procedures used:

We cannot conceal, however, our concerns about some of the procedures followed by the Commission in the rule-making process by which the program was adopted. The Commission complied but barely with the procedures mandated by the Administrative Procedure Act for notice and comment rule-making, 5 U.S.C. \&553 (1976). . . . At almost every step of the way, the NRC's procedures were less than exemplary. The notice of proposed rule-making was cursory and gave the industry the minimum acceptable opportunity to respond. The agency's statement of the basis for the program in its final form provided limited technical guidance indeed. ... If the NRC treats the safeguards of the administrative process in too cavalier a fashion .... it may be impossible for the reviewing court to discern that its action has indeed furthered the public safety. ${ }^{64}$

Notwithstandimg the minimal procedural protections provided by the NRC, the court, following the directive of Vermont Yankee, affirmed the agency's rule.65

But a number of courts read Vermont Yankee as limiting only procedural review, not review of substance or agency reasoning, and soine

61. See 42 U.S.C. $\S \S 2201(\mathrm{i}), 5841(\mathrm{f})$ (1976).

62. Connecticut Light \& Power, 673 F.2d at 527.

63. Id at 536 .

64. Id. at $528,536-37$.

65. Another example of judicial deference to informal agency action is seen in Home Health Servs. of the United States, Inc. v. Schweiker, 683 F.2d 353 (11th Cir. 1982). The court upheld a decision concerning medical provider costs made by the Provider Reimbursenent Revicw Board of the Department of Health and Human Services. The Board relied on several surveys whose reliability the court (and even the Board) admitted was "questionable," 683 F.2d at 357, yet the court deferred to the Board's judgment and upheld its decision. The court noted that the scope of review was limited; under "this narrow standard of review, a court lacks the power to substitute its judgment for that of the administrative agency. If the agency's findings are supported by substantial evidence and are not arbitrary or capricious, the reviewing court cannot reverse the findings of the agency on the basis that it would have decided the case differently." 683 F.2d at 356-57.

Particularly after Vermont Yankee, several courts of appeals have appeared to give less than a hard look to informal agency decisionmaking. See Rockford League of Women Voters v. NRC, 679 F.2d 1218, 1220-21 (7th Cir. 1982)(not only upholding agency inaction but also refusing to scrutinize possible agency departure from settled course of action). But see Nueces County Navigation Dist. No. 1 v. ICC, 674 F.2d 1055, 1063-64 (5th Cir. 1982)(agency must adequately explain departure from previous policy so that reviewing court may determine reasonableness of that departure). 
judges suggested that Vermont Yankee mandated heightened judicial scrutiny of the substance of agency rulemaking. ${ }^{66}$ In Natural Resources Defense Council, Inc. v. NRC, ${ }^{67}$ the case arising from the remand in Vermont Yankee, Judge Bazelon wrote a lengthy and technical opinion $^{68}$ agam vacating the NRC's rules concerning the lack of necessity for individualized consideration of the environmental impact of the reprocessing, storage, and disposal of spent nuclear fuel (the "back end" of the fuel cycle). The court sifted through a mass of complex technical data to conclude that the rule failed "to allow for consideration of uncertainties underlying [the Commission's] assumption that no radiological effluents will be released into the biosphere once wastes are sealed in a permanent repository" (the "zero release" assumption). ${ }^{69}$ The court found that the rule was not based on a "consideration of the relevant factors"- the "health, socioeconomic, and cuinulative effects of fuel-cycle activities"70 - and was thus arbitrary and capricious. ${ }^{71}$

66. See, for example, the comments of Judge McGowan:

In informal rulemaking, as elsewhere, fair procedures tend to assume fair results; and a reviewing court that rigidly insists upon the one can, for that very reason, be justifiably less exacting in its scrutiny of the other.

It is for this reason that I view with some apprehension the Supreme Court's ban in Vermont Yankee on judicially directed expansion, on occasion, of the APA's requirements for informal rulemaking. Its consequence may be that courts, deprived of this resource, may feel compelled, at the substantive review level, to probe more deeply into the scientific and technical matters in respect of which they have very limited competence at best, with the risk of thereby frustrating the work of the experts into whose care those matters have been given.

McGowan, supra note 5, at 695.

67. 685 F.2d 459 (D.C. Cir. 1982), rev'd sub nom. Baltimore Gas \& Elec. Co. v. Natural Resources Defense Council, 103 S.Ct. 2246 (1983). The Supreme Court held that the Court of Appeals had gone beyond its proper role of assuring that the agency had adequately considered the environmental impact of its action and suggested that courts should leave the "fundamental policy question" of nuclear power development to the Congress. Balimore Gas \& Elec., $103 \mathrm{~S}$. Ct. at 2252 .

68. It is even more striking that this "substantive review" opinion was written by Judge Bazelon, whose pre-Vermont Yankee stance on strict procedural review rested upon "his conclusion that judges are 'institutionally incompetent' to weigh evidence, even to make an 'arbitrary and capricious' determination, in rulemaking proceedings involving highly technical and complex areas." Raymond, A Vermont Yankee in King Burger's Court: Constraints on Judicial Review Under NEPA, 7 B.C. ENvTL. AFF. L. REv. 629, 642 (1979)(citations omitted). Before Vermont Yankee, Judge Bazelon had made clear that "judicial review of technical agency decisions ought to concentrate on procedures, not the merits." Rodgers, supra note 44 , at 713 .

69. 685 F.2d at 477.

70. Id. at 494.

71. Id. at 485 (quoting Bowman Transp., Inc. v. Arkansas-Best Freight Sys., 419 U.S. 281, 285 (1974)). The court also concluded that the NRC's failure to disclose the uncertainties of the zero release assumption violated the National Environmental Pohcy Act of 1969 (NEPA), 42 U.S.C. $\$ 4332$ (1976), and was therefore "not in accordance with law" as required under section $706(2)$ (A) of the APA, 685 F.2d at 489. Judge Wilkey, who dissented, accused the majority of ignoring

clear directions to the contrary froin the Supreme Court [in Vermont Yankee and of applying a standard that is] best described as requiring "too hard a look." . . . Judge 
Unlike the Natural Resources Defense Council case, which struck down a generic rule after the agency had reached a reasoned decision because the court disagreed with the results, other courts have closely scrutinized agencies' decisionmaking processes to ensure that the agencies have presented well-reasoned and well-articulated explanations of their actions. Without such an explanation, a reviewing court cannot effectively exercise its responsibility to oversee agency action. ${ }^{72}$ This approach, of course, circumvents the kind of case-by-case judicial creation of hybrid rulemaking procedures that the Court denounced in Vermont Yankee. Yet this approach may have the same effect as hybrid procedures, because the threat of remand for a "clearer explanation" often prompts the agency to employ additional procedures to develop further its records in case of appeal and review.

Effects analogous to hybrid rulemaking were apparent in the challenge to the Federal Communication Commission's decision to renew the license of a television station in Central Florida Enterprises v. FCC (Central Florida I) ${ }^{73}$ in which the Court of Appeals for the District of Columbia Circuit vacated the FCC's decision. The court lield that the FCC madequately investigated and analyzed certain factors weighing against the renewal and had not "even vaguely described" the process by which it weighed those factors. ${ }^{74}$ The court stated that "the Commission's handling of the facts of this case [nade it] embarrassingly clear that the FCC practically erected a presumption of renewal that is inconsistent with the full hearing requirement"75 of the Communications Act. ${ }^{76}$ The court remanded the case to the agency with instructions to the FCC to cure those deficiencies.

Bazelon's majority opinion has braided from NEPA, the APA, and his own perceptions of public good a novel standard of substantive and procedural scrutiny of NRC activity which we as a court are unauthorized to create and ill-equipped to manage.

685 F.2d at 517 (Wilkey, J., dissenting). The Supreme Court apparently agreed with Judge Wilkey and reversed the majority.

72. Judge Wald summed up this view as follows:

Collectively, these concerns have sometimes been expressed as a need for "reasoned decision-making" and sometimes as a need for adequate "methodology." However expressed, these more substantive concerns have been coupled with a requirement that assumptions be stated, that process be revealed, that the rejection of alternate theories or abandonment of alternate courses of action be explained and that the rationale for the ultimate decision be set forth in a manner which permits the public to exercise its statutory prerogative of comment and the courts to exercise their statutory responsibility upon review.

National Lime Ass'n v. EPA, 627 F.2d 416, 453 (D.C. Cir. 1980)(footnotes omitted); see also Recording Indus. Ass'n v. Copyright Royalty Tribunal, 662 F.2d 1, 7-11 (1981).

73. 598 F.2d 37 (D.C. Cir. 1978), cert. dismissed, 411 U.S. 957 (1979).

74. $598 \mathrm{~F} .2 \mathrm{~d}$ at 50.

75. Id. at 51 .

76. 47 U.S.C. $\S 309(e)(1976)$. 
On remand the FCC again concluded that the license should be renewed and its conclusion was again appealed to the Court of Appeals. ${ }^{77}$ This time the court affirmed the Commission's decision, holding that the prior inadequate fact-finding and analysis and faulty balancing methodology had been cured. ${ }^{78}$ The FCC had assuaged the court's concern that its analysis was too cursory and had also adopted a new policy for renewal proceedings that met the criteria of Central Florida $I$. Nevertheless, the court carefully scrutinized the FCC's new approach and specified the factors that it expected the FCC to consider in future renewal proceedings so that the "new approach [would not] degenerate into precisely the sort of irrebuttable presumption in favor of renewal that we have warned against."79 The court noted that "inuch will depend on how the Commission applies [the new standard] and fleshes it out," and subtly reminded the FCC that remand would be available to correct a decision " 'opaque to judicial review,' 'wholly unintelligible,' or based purely on 'administrative "feel.", , ",

Thus the court avoided stepping over the line drawn in Vermont Yankee by requiring a clearly articulated and well-reasoned decision yet not specifying any "hybrid" procedures. In so doing, the Central Florida court compelled an agency to develop its own additional, more fornal procedures so that it could produce an acceptable record for review. Other courts also utilized this elaboration approach to ensure that judicial review would remain an effective check on improper agency power. ${ }^{81}$ This was also at least partially the approach taken by the Court of Appeals for the District of Colunnbia Circuit in invalidating a rescission by the National Highway Traffic Safety Administration (NHTSA) of the requirement for passive restraints in many cars, a decision upheld by the Supreme Court. ${ }^{82}$ That case placed squarely before the Court the question whether the elaboration approacli to judicial review of informal administrative action-a requirement of reasoned decisionmaking evident from the record-was permissible.

77. Central Florida Enters. v. FCC (Central Florida II), 683 F.2d 503 (D.C. Cir. 1982), cert. denied, 103 S. Ct. 1774 (1983).

78. 683 F.2d at 505 .

79. Id. at 508.

80. Id. (footnotes omitted)(quoting Central Florida I, 598 F.2d at 50, 59).

81. See Greyhound Corp. v. ICC, 668 F.2d 1354, 1360 (D.C. Cir. 1981)(vacating agency's action for failure to explain adequately its rejection of one test and its substitution of another as sole criterion for continuing jurisdiction); Illinois v. United States, 666 F.2d 1066, 1074-75 (7th Cir. 1981)(agency must fully explain why final decision differs from that of factfinder).

82. State Farm Mut. Auto. Ins. Co. v. DOT, 680 F.2d 206 (D.C. Cir. 1982), vacated and remanded sub nom. Motor Vehicle Mfrs. Ass'n v. State Farm Mut. Auto. Ins. Co., 103 S. Ct. 2856 (1983). 


\section{STATE FARM: Legitimizing HaRd LoOK ReviEIV}

In 1966, in response to increasing concern about the deaths and injuries resulting from motor vehicle accidents ${ }^{83}$ and recognizing the need for expertise in seeking solutions, Congress enacted the National Traffic and Motor Vehicle Safety Act ${ }^{84}$ for the purpose of reducing "traffic accidents and deaths and injuries to persons resulting from traffic accidents." 85 The Act created the National Highway Transportation Safety Administration (NHTSA) and gave it authority to issue safety regulations. One of the NHTSA's regulations, the passive restraint requirenent, was at issue in State Farm. This regulation had a long, "complex and convoluted history. Over the course of approximately 60 rulemaking notices, the requirement [had] been inposed, amended, rescinded, reimposed, and now rescinded again." 86

In 1967, the Department of Transportation (DOT), parent agency to the NHTSA, issued Federal Motor Vehicle Safety Standard Number 208, which required autoinobile inanufacturers to install lap and shoulder belts in all new cars. ${ }^{87}$ The DOT found, however, that automobile

83. In $1982,46,300$ Americans died in such accidents. NATIONAL SAFETY Council, 1982 Motor Vehicle Deaths by States (May 16, 1983).

84. 15 U.S.C. $\$ \S 1381-1431$ (1982)(hereinafter cited as "the Act").

85. 15 U.S.C. $\$ 1381$ (1982). Thus the NHTSA can act to prevent accidents and/or to prevent injuries in the event of accidents-especially those arising from the " 'second collision'-the impact of the individual within the vehicle against the steering wheel, dashboard, windshield, etc.-[which had] been largely neglected." S. REP. No. 1301, 89th Cong., 2d Sess. 2-3, reprinted in 1966 U.S. Code Cong. \& AD. News 2709, 2710-11. The Act directs the Secretary of Transportation or his delegate (the Secretary's authority under the Act to promulgate safety standards has been delegated to the Administrator of the NHTSA. 49 C.F.R. $\S 1.50$ (a) (1982)) to issue motor vehicle safety standards that "shall be practicable, shall mcet the need for motor vehicle safety, and shall be stated in objective terms," 15 U.S.C. $\$ 1392$ (a) (1982). In issuing these standards, the Secretary is directed to consider "relevant available motor vehicle safety data," whether the proposed standard "is reasonable, practicable and appropriate" for the particular type of motor vehicle, and the "extent to which such standards will contribute to carrying out the purposes" of the Act. 15 U.S.C. $§ 1392(f(1),(3),(4)$ (1982). Although Congress intended that "safety shall be the overriding consideration in the issuance of standards," it also recognized that the "Secretary will necessarily consider reasonableness of cost, feasibility and adequate lead time." S. REP. No. 1301, 89th Cong., 2d Sess. 6, reprinted in 1966 U.S. CodE CoNG. \& AD. News 2709, 2714. The Act also provides for judicial review under the provisions of section 706 of the APA of all "orders establishing, amending, or revoking a Federal motor vehicle safety standard." 15 U.S.C. § 1392(b) (1982).

86. State Farm, $103 \mathrm{~S}$. Ct. at 2862. That administrative history was accompanied by congressional activity and a good deal of litigation as well, including separate adjudications in both the Sixth Circuit and the District of Columbia Circuit. For a good overview of this history, see Graham \& Gorham, NHTSA and Passive Restraints: A Case of Arbitrary and Capricious Deregulation, 35 AD. L. REv. 193 (1983); see also the first several pages of the opinions of both the Court of Appeals and the Supreine Court, as well as Note, Seat Belts Anyone?-Department of Transportation Attempts 10 "Unbuckle" the Auto Industry from Passive Restraint Requirements: State Farm v. Department of Transportation, 14 U. ToL. L. REv. 1091, 1130-36 (1983).

87. 32 Fed. Reg. 2408, 2415 (1967). 
passengers did not use these manual seatbelts enough to reduce injuries significantly. Consequently, the agency issued a notice of proposed rulemaking in July 1969 to consider a requirennent for "passive restraint" systems, ${ }^{88}$ protective systems that would require "no action by vehicle occupants." 89 After separate lengthy rulemaking proceedings, the NHTSA in 1970 and 1971 issued revisions to Standard 208 which called for installation of passive restraints-either airbags or "passive belt" systems. ${ }^{90}$

The 1972 version of Standard 208 called for "complete passive protection" for all front seat occupants of vehicles manufactured after August 15, 1975.91 Several autoinobile manufacturers challenged the passive restraint requirements. In Chrysler Corp. v. DOT, the United States Court of Appeals for the Sixth Circuit held that the NHTSA had the statutory authority to mandate passive restraints and that the "Agency's decision to require passive restraints is supported by substantial evidence."92 The court held, however, that the compliance tests did not satisfy the Safety Act's requirement that safety standards be stated in "objective" terms ${ }^{93}$ and remanded the passive restraint provisions to the NHTSA. Meanwhile, the interlock systems which car makers had installed were becoming highly unpopular among consumers and in 1974 Congress prohibited NHTSA from enacting any standard requiring or permitting compliance by means of interlocks or continuous buzzers. ${ }^{94}$ In addition, Congress provided for a legislative veto of

88. 34 Fed. Reg. 11,148 (1969).

89. 36 Fed. Reg. 8296 (1971); see Comment, Occupant Protection in Automobiles-Airbags and Other Passive Restraints: The State of the Art, The Federal Standard and Beyond, 27 AM. U.L. REv. 635 (1978).

90. 35 Fed. Reg. 16,927, 16,928 (1970); 36 Fed. Reg. 12,858, 12,859, 12,866 (1971). "This rule was a de facto airbag mandate since no other technologies were available to comply with the standard." Graham \& Gorham, supra note 86, at 197. "The airbag is an inflatable device concealed in the dashboard and steering column. It automatically inflates when a sensor indicates that deceleration forces from an accident have exceeded a preset minimum, then rapidly deflates to dissipate those forces." State Farm, 103 S. Ct. at 2862. However, in 1971 NHTSA recognized that some "passive belt" systems might meet the requirements of Modifled Standard 208 and added a new section providing for passive belts, as long as "emergency release" mechanisms were present. 36 Fed. Reg. 12,858, 12,859, 12,866 (1971).

91. The standard allowed compliance in the interim by either passive restraints or seat belts coupled with "ignition interlock devices" that would prevent starting the vehicle if the belts were not connected. 37 Fed. Reg. 3911 (1972). Most car manufacturers chose the interlock system. 41 Fed. Reg. 24,070 n.3 (1976)(only a few luxury GM cars were equipped with airbags).

92. 472 F.2d 659, 675 (6th Cir. 1972).

93. Id. at $675-78$.

94. The Motor Vehicle and Schoolbus Safety Amendments of 1974, Pub. L. No. 93-492, $\S 109,88$ Stat. 1482, 15 U.S.C. $\$ 1410$ (c)(1) (1982). 
any future standard that could be satisfied by any system other than manual seatbelts. 95

The agency postponed the effective date for passive restraint systems to August 31, 1976 but emphasized that the delay was only temporary. ${ }^{96}$ In June 1976, however, Secretary of Transportation William T. Coleman initiated a new rulemaking on the issue ${ }^{97}$ and decided to suspend the passive restraint requirement. In its place Coleman proposed a large scale demonstration project involving up to a half a million automobiles. 98

Brock Adams, appointed by Jimmy Carter to succeed Coleman as Secretary of Transportation, did not agree that the demonstration project was necessary. He reopened rulemaking on the topic a few months after assuming office ${ }^{99}$ and soon issued a new mandatory passive restraint regulation to take effect beginning in 1981.100 Botll airbags and passive belts would satisfy the standard.

Once again, Modified Standard 208 was challenged in court and in Congress. In Pacific Legal Foundation v. DOT, ${ }^{101}$ the United States Court of Appeals for the District of Columbia Circuit upheld Modified Standard 208 as a rational, nonarbitrary regulation within the agency's authority. The court noted that Adams's policy was a clear departure from the decision of Secretary Coleman but held that Adams had "provided a sufficient explanation wlyy his judgment differed from lis predecessor's." 102 In Congress, although opposition surfaced, neither house

95. 15 U.S.C. $\S 1410 \mathrm{~b}(\mathrm{c})(2)$ (1982). The House passed by a vote of $339-49$ an amendment that would have repealed the DOT's authority to require passive restraint systems but this provision was dropped by the conference committee in lieu of the legislative veto provision. Mandatory Seatbelt System Voided, Congressional QuarTerly Almanac 685-88 (1974).

96. 40 Fed. Reg. 33,977 (1975). "The NHTSA intends to propose the long-term requirements for occupant crash protection . . . as soon as possible." Id.

97. 41 Fed. Reg. 24,070 (1976).

98. Coleman, who found passive restraints economically and technically feasible, suspended the mandatory standard because he expected widespread public opposition to it. DEPARTMENT of Transportation, The Secretary's Decision Concerning Motor Vehicle Occupant Crash Protection 8, 10-12 (Dec. 6, 1976).

99. 43 Fed. Reg. 15,935 (1977).

100. 42 Fed. Reg. 34,289 (1977). Modified Standard 208 ordered a phasing in of passive restraints starting with large cars in 1982, mid-size cars in 1983, and small cars in 1984. Under the NHTSA's assumptions, an estimated 9000 lives would be saved and 65,000 serious injuries would be avoided annually. 42 Fed. Reg. 34,297-99 (1977).

101. 593 F.2d 1338, 1339-40 (D.C. Cir.)(Petitioner Pacific Legal Foundation opposed passive restraints and asked the court to overturn the standard, while Petitioner Public Citizen wished to accelerate the timetable for requiring installation of those restraints), cert. denied, 444 U.S. 830 (1979).

102. 593 F.2d at 1346.

103. The full House of Representatives did not take any action on this matter. The Senate, on committee recommendation, tabled a resolution of disapproval. 123 CoNG. REC. 33,332 (1977). 
exercised its authority to veto the standard. ${ }^{103}$ The car manufacturers, albeit reluctantly, geared up to comply with the 1982 deadline.

The deadline for compliance was fast approaching when Ronald Reagan appointed Drew Lewis as Secretary of Transportation. Within a month after taking office, Lewis reopened the rulemakmg process due to drastically changed economic circumstances and particularly the economic "difficulties of the automobile industry." 104 In April, the NHTSA granted car makers a one-year delay in complying with the large car deadline and announced plans to reexamme the passive restraint issue with an eye towards possible rescission. ${ }^{105}$ In October 1981 the NHTSA issued a final rule (Notice 25) that rescinded the passive restraint requirement of Modified Standard 208. ${ }^{106}$

\section{A. The Court of Appeals Decision in State Farm.}

State Farm Mutual Automobile Insurance Company and the National Association of Independent Insurers filed petitions for review of the NHTSA's decision to rescind Modified Standard 208. In State Farm Mutual Automobile Insurance Co. v. Department of Transporta-

Congress did pass riders to DOT appropriations bills for 1979 and 1980 that prohibited the Department from spending funds to enforce the passive restraint requirements. See DOT and Related Agencies Appropriations Act, 1979, Pub. L. No. 95-335, \& 317, 92 Stat. 435, 450 (1978); DOT \& Related Agencies Approp. Act, 1980, Pub. L. No. 96-131, § 317(a), 93 Stat. 1023, 1039 (1979). Because the standard was not scheduled for implementation until 1981, the riders had only symbolic effect. Other proposals to modify the standard (particularly the "Stockman Amendment" of 1979 which would have required NHTSA to allow manual belts as a means to satisfy the requirement, 125 CoNG. REC. 36,924-25 (Dec. 19, 1979)) failed to become law and Standard 208 remained in effect.

104. 46 Fed. Reg. 12,033 (1981). The action was in line with President Reagan's Executive Order of February 17, which ordered agencies to suspend or postpone the effective date of all major regulations that had not yet taken effect. A major regulation was defined as one likely to have an annual effect on the economy of $\$ 100$ million or more. Exec. Order No. 12,291, 3 C.F.R. 127, 131-32, § 7(a), 127, § l(b)(1) (1982), reprinted in 5 U.S.C.A. $\$ 601$ (West Supp. 1983).

105. 46 Fed. Reg. 21,172, 21,205 (1981). The White House Press Office announced these decisions on April 6, 1981, as part of a larger package of economic recovery measures.

106. Id. at 53,419 . The agency maintained that it no longer could find that the passive restraint requirement would produce significant safety benefits. Id. The agency argued that if Standard 208 were to go into effect it was "reasonably certam" that "the overwhelming majority of new cars would [have been] equipped with autoinatic belts that are detachable," 46 Fed. Reg. at 53,421 , and would be the functional equivalent of manual belts and would not lead to any significant increase in the usage of restraints. Id. at 53,421,53,423. The NHTSA concluded that the costs of the requirement (approximately one billion dollars) were unreasonable and thus the requirements were "impracticable." Id. at 53,423. The agency also rejected the option of amending the standard to require "use-inducing features" on automatic belts for several reasons. It rejected this amendment for reasons of cost, the inequity of making current regular users of manual belts pay for a system that was unnecessary for them (and subsidize current nonusers), the adverse public and congressional reaction such a requirement would be expected to cause in light of the "widespread, latent and irrational fear in many members of the public that they could be trapped by the seat belt after a crash," and "compelling safety reasons." Id. at 53,423, 53,424. 
tion, ${ }^{107}$ the appellate court found the rescission to be arbitrary and capricious. The court held that the appropriate standard of judicial review under the Safety Act and the APA was the arbitrary and capricious test, rejecting the Sixth Circuit's conclusion in Chrysler Corp. v. Department of Transportation that the Safety Act required application of the "substantial evidence" standard. ${ }^{108}$

The court of appeals observed that the appropriate scope of review remains the inost troublesome question in this case, however, because we are called upon to review the rescission rather than the promulgation of an agency rule. The scope of review in such a situation appears to be a matter of first impression, even though judicial review of orders revoking a standard is specifically authorized by the Safety Act and the APA. 109

The court noted the resemblance between rescission and an agency's refusal to act, which is subject to only cursory judicial review, but ultimately it rejected such deferential review for rescissions. The court said that two sources suggested the appropriate standard. First, the $P a$ cific Legal Foundation case had explained that "probing" review was necessary where an agency has departed from a settled course of action. ${ }^{110}$ Second, the court read the legislative reaction to the passive restramt standard as one of support and believed any rescission of that standard must be subject to searching and careful review. ${ }^{111}$

Under this intensified scope of review, the court reviewed the rescission and found it "arbitrary and illogical" for two reasons. ${ }^{112}$ First, because the agency offered "not one iota of evidence" that seatbelt usage would fail to increase as earlier studies had predicted, the NHTSA had made "no showing that the standard is unjustified as written."113 The agency's finding that the standard should be rescinded due to "substantial uncertainty" about increased usage rates turns the "ques-

107. 680 F.2d 206 (D.C. Cir. 1982), vacated \& remanded sub nom. Motor Vehicle Mfrs. Ass'n v. State Farm Mut. Auto. Ins. Co., 103 S. Ct. 2856 (1983). For a good critical analysis of the Court of Appeals decision, see Graham \& Gorham, supra note 86.

108. 680 F.2d at 218-20 (rejecting Sixth Circuit's conclusion in Chrysler Corp. v. DOT, 472 F.2d 659, 668 (6th Cir. 1972) that the Safety Act's mandate that "all of the evidence before thc agency . . . shall be included in the record" invokes the substantial evidence test).

109. State Farm, 680 F.2d at 218.

110. 593 F.2d at 1343 (applying "thorough, probing, in-depth" review of Secretary Adams's decision to issue Modified Standard 208 only four months after Secretary Coleman had decided otherwise); see Joseph v. FCC, 404 F.2d 207, 212 (D.C. Cir. 1968)(sharp changes of course constitute "danger signals" to which a reviewing court must be alert); see also Greater Boston Television Corp. v. FCC, 444 F.2d 841, 852 (D.C. Cir.)("Judicial vigilance . . . is particularly called upon where . . . the Cominission's policies are in flux."), cert. denied, 403 U.S. 923 (1971).

111. State Farm, 680 F.2d at 222-28.

112. Id. at 230 .

113. Id. at $230-31$. 
tion on its head. . . . NHTSA has some burden . . . to show that a regulation once considered to prevent deaths and mjuries efficiently can no longer be expected to do so." 114

The second and more important reason why the majority of the court ${ }^{115}$ found the rescission unlawful was because the "NHTSA has failed to consider or analyze obvious alternatives to rescission, and has thus artificially foreclosed attempts to further the purpose of the Safety Act." 116 Although the NHTSA did consider a few alternatives such as changing the sequence of large car-small car comphance, it did not devote "even a modicum of reasoned analysis to several far more obvious possible amendments to Modified Standard 208"117_notably, rejecting detachable belts as a means of comphance, ${ }^{118}$ reinstating Secretary Coleman's demonstration project, ${ }^{119}$ or adopting an airbagsonly standard. ${ }^{120}$ The court acknowledged that the agency was not obhigated to consider every alternative but imsisted that it at least consider and discuss some obvious alternatives. ${ }^{121}$

The Court of Appeals concluded that

[o]n balance, it is difficult to find anything positive to say about NHTSA's decisionmaking in this case [or] to avoid the conclusion that NHTSA's analysis in Notice 25 has been distorted by solicitude for the economically depressed automobile industry-which is not the agency's mandate-at the expense of consideration of traffic safety, which is. ${ }^{122}$

Therefore the court vacated the rescission and remanded the case to the NHTSA. ${ }^{123}$ The Motor Vehicles Manufacturers Association and the

114. Id. at 231.

115. Judge Edwards, who concurred in the decision, did not accept this second reason as a basis for decision. Id. at 242.

116. Id. at 230 .

117. Id. at 233 .

118. Id. at 233-36.

119. Id. at 238-39.

120. Id. at 236-38. "If NHTSA's consideration of contmuous belts was minimal, its analysis of airbags was nonexistent." Id. at 236.

121. The court stated that it was not holding that an agency could never rescind a safety standard, but "rescission must be supported by rational explanations, after a reasoned and goodfaith effort to consider alternative means of advancing the agency's purpose." Id. at 240 .

122. Id. at $239-40$ (footnote omitted).

123. In the order of June 1, 1982, the court gave the NHTSA only 30 days in which to "submit a schedule for resolving the questions raised in this opmion, leading either to the rescission or suspension of the standard or to a judicially approved schedule for the effective implementation of that standard or an amended standard." Id. at 242 . The court concluded that it "should not simply remand this petition to the agency so that recalcitrance might succeed where rational decisionmaking might not. The implementation of a passive restraint standard has already been delayed without acceptable reasons, perhaps unconscionably so." $I d$. at 241 . The agency subsequently submitted to the court a notice of proposed mlemaking, Docket No. 74-14, Notice 28, FMVSS 208, and on August 4, 1982 the court issued an order staying the compliance date for the 
Solicitor General petitioned the Supreme Court for review of the appellate court's decision.

\section{B. Motor Vehicles Manufacturers Association v. State Farm Mutual Automobile Insurance Co.: The Supreme Court Opinion.}

The Supreme Court found, as liad the Court of Appeals, that the NHTSA's rescission of the passive restraint requirement was arbitrary and capricious. ${ }^{124}$ The Court held that, under the language of the Motor Vehicle Safety Act, which specifies that the review provisions of the APA apply to "all orders establishing, amending, or revoking" an automobile safety standard, the rescission of a standard is subject to the same test as the promulgation of sucl a standard-the arbitrary and capricious standard as described in Overton Park. ${ }^{125}$ The Court summarily rejected the claim of the Motor Vehicle Manufacturers Association (MVMA) that the proper standard to judge rescission was that which a court would use to judge an agency's refusal to promulgate a rule im the first place, which would be "close to the borderlime of nonreviewability." 126 The Court noted that to accept this view would "render meaningless the review provisions of the Safety Act."127 In addition, the Court noted the substantial differences between revocation of an existing regulation and a failure to act at all. Rescission is a reversal of the agency's former views on how best to carry out the policies committed to it by Congress and faces the "presumption that those policies will be carried out best if the settled rule is adhered to.' . . A Accordingly, an agency changing its course by rescinding a rule is

passive restraint standard until September 1, 1983. In effect, the court reinstated Standard 208 but postponed the compliance date. This action by the court of appeals in reinstating the standard was one of the major issues in the petitioners' briefs to the Supreme Court. Car manufacturers and the government contended that setting such implementation dates intruded upon agency authority and violated Vermont Yankee's injunction agamst imposing time constraints. Petitioner Motor Vehicle Manufacturers Association (MVMA) Opening Brief at 45-48, and Brief for the Federal Parties at 47-49, State Farm, 103 S. Ct. 2856 (1983). The respondents argued that the court of appeals simply delayed the effective date of the standard, which, because it had not been validly rescinded, was in effect and required imstallation of passive restraints after Septeinber 1, 1982. Brief of Respondent State Farm Mutual Automobile Insurance Company at 44-49, State Farm, 103 S. Ct. 2856. The Supreme Court, however, did not decide this issue because it held that the agency had sufficient justification to suspend Standard 208 pending the further consideration required by the Court of Appeals and the Supreme Court. State Farm, $103 \mathrm{~S}$. Ct. at 2783 n.21.

124. The Chief Justice and Justices Rehnquist, Powell, and O'Connor dissented as to the finding that the decision to rescind the detachable belt portion of the Standard was arbitrary and capricious but joined in the opinion on all other matters. State Farm, $103 \mathrm{~S}$. Ct. at 2874-75 (Rehnquist, J., dissenting in part, concurring in part).

125. Id. at 2865 .

126. Id. at 2856 (referring to brief of Petitioner MVMA).

127. State Farm, 103 S. Ct. at 2866. 
obligated to supply a reasoned analysis for the change beyond that which may be required when an agency does not act in the first instance." 128

The Court next turned to the court of appeals' use of congressional acts and nonacts and held that the court had "erred in intensifying the scope of its review based upon its reading of legislative events." $129 \mathrm{Al}$ though the Court concluded that it is difficult to infer congressional support for passive restraints froin inchoate legislative action such as Congress's unwillingness to exercise its veto power, ${ }^{130}$ it stated that in any event the standard of review is not enlarged or diminished by subsequent congressional action. ${ }^{131}$ Even an "unequivocal ratification" by Congress would not connote disapproval of a later decision to rescind the regulation. ${ }^{132}$ "That decision remains subject to the arbitrary and capricious standard."133

Applying that standard, the Court dealt separately with the rescission as applied to airbags and to seatbelts. "The first and most obvious reason for finding the rescission arbitrary and capricious is that NHTSA apparently gave no consideration whatever to inodifying the Standard to require that airbag technology be utilized."134 Even if the agency correctly concluded that detachable belts will not attain anticipated safety benefits, ${ }^{135}$ this would only justify amending Standard 208 to disallow coinpliance by detachable belts, because the agency never repudiated the efficacy of the airbag system. The Safety Act still required the agency to achieve traffic safety, and because the NHTSA did not even consider whether airbags would advance that goal, the Court rejected the agency's analysis as incomplete. ${ }^{136}$

128. Id. (footnote omitted)(quoting Atchison, T. \& S.F. Ry. v. Wichita Bd. of Trade, 412 U.S. 800, 807-08 (1973)).

129. State Farm, 103 S. Ct. at 2867.

130. Id. at 2868. The Court noted that the post-enactment legislative events could also be read as showing congressional hostility to the restraints.

131. Id. at $2867-68$.

132. Id. at 2868.

133. $I d$.

134. $I d$.

135. See infra notes 104-06 and accompanying text.

136. State Farm, 103 S. Ct. at 2869.

[T] he mandate of the Safety Act to achieve traffic safety would suggest that the logical response to the faults of detachable seatbelts would be to require the installation of airbags. At the very least this alternative way of achieving the objectives of the Act should have been addressed and adequate reasons given for its abandonment. But the agency not only did not require compliance through airbags, it did not even consider the possibility in its 1981 rulemaking. . . . Because, as the Court of Appeals stated, "NHTSA's . . . analysis of airbags was nonexistent," . . . what we said in Burlington Truck Lines v. United States . . . is apropos lere: "There are no findings and no analysis here to justify the choice inade, no indication of the basis on which the [agency] 
The State Farm Court dispensed with two counterarguments concerning the airbags-only option. First, just because the automobile industry opted for the passive belt, which the NHTSA considers ineffective, this "hardly constitutes cause to revoke the standard itself. Indeed, the Motor Vehicle Safety Act was necessary because the industry was not sufficiently responsive to safety concerns." 137 Second, the Court rejected the contention that Vermont Yankee prevented the court of appeals from requiring the agency to consider an airbags-only alternative because that would, in essence, be dictating to the agency the procedures it was to follow. ${ }^{138}$ The Court said such a contention misreads Vermont Yankee "as though it were a tahisinan under which any agency decision is by definition unimpeachable"; in reahty, Vermont Yankee held only that courts could not impose additional procedural requirements upon agencies. ${ }^{139}$ No court required the NHTSA to follow any specific procedures nor even required it to consider all policy alternatives in reaching its decision. But because the NHTSA had previously decided that airbags met the mandate of the Safety Act, it could not abandon that technology without reasoned analysis and explanation. 140

The State Farm Court then turned to consideration of the rescission as it applied to seatbelts, which it adınitted was a closer issue than the airbags-only decision. ${ }^{141}$ It held that this decision was also arbitrary and capricious, even though the Court agreed with petitioners' contention that "just as an agency reasonably may decline to issue a safety standard if it is uncertain about its efficacy, an agency may also revoke a standard on the basis of serious uncertainties if supported by

exercised its expert discretion. We are not prepared to and the Administrative Procedure

Act will not permit us to accept such . . . practice."

Id. (quoting Burlington Truck Lines v. United States, 371 U.S. 156, 167 (1962)).

137. State Farm, $103 \mathrm{~S}$. Ct. at 2870 . The Court noted that "for nearly a decade, the automobile industry waged the regulatory equivalent of war against the airbag and lost." Id. (footnote omitted).

138. Id.

139. Id.

140. "We hold only that given the judgment made in 1977 that airbags are an effective and cost-beneficial life-saving technology, the mandatory passive-restraint rule may not be abandoncd without any consideration whatsoever of an airbags-only requirement." Id. at 2871.

141. Id. at 2871. Justice Rehnquist, in a dissenting opinion, disagreed with the majority's conclusion that the NHTSA's view of detachable automatic seatbelts was arbitrary and capricious. Id. at 2874-75 (Rehnquist, J., dissenting). The dissent pointed to the agency's commitment to increasing its educational efforts and to persuading the industry to develop automatic crash protection technology. Id. at 2875. The dissenters also demonstrated a willingness to grant more latitude to new administrations to give different weights to certain factors and thus come to different conclusions than their "counterparts in a previous administration." Id. at 2875; see also infra notes $153-58$ and accoinpanying text. 
the record and reasonably explained." 142 But the Court held that it is not sufficient for "an agency to merely recite the terms 'substantial uncertainty' as a justification for its actions. ${ }^{143}$ The agency must explain the evidence that is available, and inust offer a 'rational connection between the facts found and the choice made." "144 Because the NHTSA did not explain why it proceeded with rescission without finding further evidence on seatbelt usage, its explanation was not sufficient to persuade the Court that it was the product of reasoned decisionmaking. 145 The Supreme Court vacated the judginent of the court of appeals and remanded the case to the court with directions to remand the matter to NHTSA for further consideration, articulation, and analysis. ${ }^{146}$

\section{IMPlications OF THE STATE FARM Decision}

The Court's decision in State Farm answered several questions, includimg a number left open by Vermont Yankee, but it left some issues unresolved. This section analyzes the major implications of State Farm-the vahidation of the hard look concept, the specification of what aspects of "legislative history" courts may consider significant, and the suggestion that courts' concern for ensuring that the "public

142. Siate Farm, 103 S. Ct. at 2871.

143. Id.

144. Id. (quoting Burlington Truck Lines v. United States, 371 U.S. 156, 168 (1962)). Even accepting the agency's judgment that the earlier field tests of passive restraints were inconclusive, the Court found grounds to believe that usage would increase with detachable passive belts over the present inanual belt due to inertia. At the very least the NHTSA "nuust bring its expertise to bear on the question," and while costs as well as benefits should be considered, the agency must always keep in inind that "Congress intended safety to be the preeminent factor under the Motor Vehicle Safety Act." State Farm, 103 S. Ct. at 2872-73.

145. " An agency's view of what is in the public interest may change, either with or without a change in circumstances. But an agency changing its course must supply a reasoned analysis." Siate Farm, $103 \mathrm{~S}$. Ct. at 2874 (quoting Greater Boston Television Corp. v. FCC, 444 F.2d 841, 852 (D.C. Cir.), cert. denied, 403 U.S. 923 (1971)).

146. State Farm, 103 S. Ct. at 2874. Roger B. Smith, Chairman of General Motors, urged the Reagan Administration to delay any rulemaking on airbags until an independent study cleared up the "massive misinformation" on the issue. He argued that "at least a decade must pass before airbags or any other passive-restraint systein could be standard equipment on virtually every car." Washington Post, Aug. 30, 1983, at D7, col. 1.

In late 1983 the United States Court of Appeals for the District of Columbia Circuit considered the decision by the Secretary of Labor to reverse a longstanding policy against allowing employment of workers in their home in the knitted outerwear industry by rescinding "liomework" regulations. 46 Fed. Reg. 50,348 (1981). In International Ladies Garment Workers' Union v. Donovan, 722 F.2d 795 (D.C. Cir. 1983), the court applied the arbitrary and capricious standard as set forth in State Farm to find the rescission unlawful because the Secretary had failed to provide a reasoned explanation of his rejection of alternatives, id. at 815 , and of his conclusion that enforcement of fair labor standards would be feasible after loinework restrictions were lifted. Id. at $818-26$. 
interest" is heard in administrative decisionmaking may be proper. This section then discusses several unresolved issues, mcluding the extent of the holding, the necessity that an agency consider alternatives, and the propriety of political intrusion in administrative decisionmaking.

The most significant implication of State Farm is that it did not add to the Vermont Yankee limitation on court-imposed procedures a further limitation on court review of the substance of agency rules. Especially when read in light of Vermont Yankee, the Court's decision in State Farm implies that federal courts may proceed with a hard look at the substance of agency decisionmaking. As noted earlier, ${ }^{147}$ some commentators and courts read the tenor of Vermont Yankee as a retreat from close review of agency action. ${ }^{148}$ Others contend that the decision was a limited procedural one or that it would not matter in any event because the basis for the hard look doctrine extended beyond the APA and because the hard look was too deeply engramed in the style of the federal courts to be excised by one decision. ${ }^{149}$ With State Farm, the "hard look" has been received into the core of judicial belief on how to review administrative action. The State Farm decision is consistent with the Overton Park and Camp opinions, which required federal courts to go beyond a superficial review of agency reasoning. Apparently, the Supreme Court did not intend Vermont Yankee to be a retreat from that line of decisions which espoused a more detailed and thorough examination of the factual bases of administrative actions, but imstead intended only to msert a procedural caveat into that reviewing process. Courts must demand from agencies careful assessment and reasoned decisionmaking as well as an adequate response to reasonable alternatives presented by challengers or to sensible arguments that arise in the course of review.

A second implication of State Farm concerns reviewing courts' use of legislative "history." The Supreme Court repudiated the court of appeals' use of congressional reactions to the passive restraint standard. The court of appeals interpreted scattered legislative acts and nonacts as a commitment to passive restraints and heightened its review of the NHTSA's actions as a result. The Supreme Court considered this "misguided," 150 even if the court had correctly gauged Congress's senti-

147. See supra text accompanying notes $57-59$

148. See, e.g., Verkuil, supra note 35 , at 427.

149. See, e.g., Rodgers, supra note 44 , at 708 .

150. State Farm, $103 \mathrm{~S}$. Ct. at 2867. As Graham \& Gorham point out, the District of Columbia Circuit's view that Congress was highly supportive of Standard 208 is questionable. Graham \& Gorham, supra note 86 , at $208-11$. 
ments. The Court thus warned lower courts that congressional action, short of statutory incorporation of agency decisions, subsequent to passage of the agency's enabling statute cannot be used by courts to infer a mandate for or against a particular type of regulation and, therefore, cannot be used to alter the standard of review. To rule otherwise, according to the Court, would violate established law, which holds that it is the intent of the Congress that passes the act that is controlling, not unenacted views of later Congresses. Such use of subsequent legislative "history" also approaches the limits of constitutionality by allowing Congress to "legislate" without meeting the constitutional requirements for making laws. ${ }^{151}$

Coupled with the legislative veto decision of the same term, ${ }^{152}$ this holding in State Farm provides a strong indication to Congress that if it wishes to direct or change administrative actions, it inust do so by positive statutory action. The courts will not read into indirect actions a directive to an agency nor allow Congress simply to negate agency action after it has delegated much policymaking power to the agency.

The Court also dealt with the issue of the "politics" of administrative behavior. Agencies are involved in politics in the sense that they must balance the claims of competing private interests in much the same way as an elected representative. ${ }^{153}$ The majority in State Farm seems, at times, to accept the view that an agency's policy emphasis may shift due to changes in its political environment, ${ }^{154}$ but commentators warn of the potential for agencies to become "captured" by the interests that they serve or are supposed to regulate. ${ }^{155}$ The panel of

151. See Graham \& Gorham, supra note 86 , at 207-08.

152. Immigration \& Naturalization Serv. v. Chadha, 103 S. Ct. 2764 (1983). For a discussion of the implications of the case, see Strauss, Was There a Baby in the Bathwater? A Comment on the Supreme Court's Legislative Veto Decision, 1983 DukE L.J. 789.

153. "Today, the exercise of agency discretion is inevitably seen as the essentially legislative process of adjusting the competing claims of various private interests affected by agency policy. ... The required balancing of policies is an inherently discretionary, ultimately political procedure." Stewart, The Reformation of American Administrative Law, 88 HARV. L. REv. 1669, 1683-84 (1975)(footnote oinitted).

154. The Court noted that an agency's " 'view of what is in the public interest may change, either with or witlout a change in circumstances.'" State Farm, $103 \mathrm{~S}$. Ct. at 2874 (quoting Greater Boston Television Corp. v. FCC, 444 F.2d 841, 852 (D.C. Cir.), cert. denied, 403 U.S. 923 (1971)).

155. See, e.g., F. Heffron \& N. McFeeley, The Administrative Regulatory Process 147-65 (1983); B. Owen \& R. Braeutigam, The Regulation Game: Strategic Use of the ADMINISTRATIVE PROCESS 10 (1978). DeLong notes the results of a changing judicial perception of agency behavior:

The phenomenon of capture has eroded the degree of automatic deference paid to oldstyle agencies. . . . [There] is the fear that the capture scenario will recur, that regulated interests will gain control of an agency and either subvert the process or use it as a tool of their own. . . O One perceptive political writer has characterized contemporary govern- 
the United States Court of Appeals for the District of Columbia Circuit in State Farm held this view at least to a degree. The court noted that the 'NHTSA's analysis . . . has been distorted by solicitude for the econounically depressed automobile industry-which is not the agency's mandate - at the expense of consideration of traffic safety, which is." 156

Although the majority of the Supreme Court in State Farm accepted the notion that politics may legitimately affect agency actions, it shared, at least to a limited extent, the perception that the automobile industry had untoward influence in the NHTSA after 1980. It noted that because Congress passed the Safety Act to force safety onto unwilling car manufacturers, the NHTSA's deferral to those manufacturers' wishes violated the congressional mandate. ${ }^{157}$ The Court seems to be saymg that agencies' ability to respond to powerful political forces in their regulatory environments is not unlimited, especially if those forces are the regulated industries themselves. This is especially true when it is not just private interests that are competing within the administrative arena, but private interests versus the larger public interest in traffic safety. Administrative pluralism may work well in the first situation when private interests battle on equal terms for agency favor; but it does not work when the amorphous public interest goes undefended. Courts generally feel they must impose stricter standards of review to ensure that the vague public interest does not go unlieard, ${ }^{158}$ at least in the area of safety regulation.

The Court also established the proper scope of review to be used when an agency rescinds a rule. The petitioners in State Farm argued that rescission is similar to refusal to promulgate a rule in the first place and thus that judicial review should be similarly deferential159-indeed, "close to the borderline of nonreviewability."160 The Supreme

ment as "the special-interest state," in which groups of all sorts have gained control of administrative units or portions of the annual budget and defended their turf ferociously.

DeLong, supra note 4, at 281 (footnotes omitted)(referring to Drew, Phase: Engagernent with the Special-Interest State, THE NEW YORKER, Feb. 27, 1978, at 64).

156. 680 F.2d at 240 .

157. State Farm, $103 \mathrm{~S}$. Ct. at 2870.

158. See, e.g., Central Florida Enters. v. FCC, 598 F.2d 37, 49-51 (D.C. Cir. 1978)(where agency has demonstrated undue bias toward private interests, presumption of agency regularity rebutted), cert. dismissed, 441 U.S. 957 (1979).

159. Petitioner's Opening Brief at 35-36, State Farm, 103 S. Ct. at 2856 (1983).

160. State Farm, $103 \mathrm{~S}$. Ct. at 2866 . For examples of judicial deference to refusal of agencies to initiate action, see generally FCC v. National Citizens Comm. for Broadcasting, 436 U.S. 775, 796-97 (1978)(upholding FCC refusal to adopt rules even if no complete factual support in the record); Southern Ry. v. ICC, 681 F.2d 29, 33 (D.C. Cir. 1982)(no power to review a discretionary decision of the ICC not to suspend a tarif); Natural Resources Defense Council, Inc. v. SEC, 606 F.2d 1031, 1058-60 (D.C. Cir. 1979)(refusing to require SEC to adopt rules in light of uncertainty); 
Court expressly rejected that view and held that "an agency changing its course by rescinding a rule is obligated to supply a reasoned analysis for the change beyond that which may be required when an agency does not act in the first instance." 161 . Thus rescission and promulgation are both subject to the same scope of review under the arbitrary and capricious standard.

The Court left open a number of questions regarding review of rescissions. The Court noted that Section 103(b) of the Safety Act states that the judicial review provisions of the APA " "shall apply to all orders establishing, amending, or revoking a Federal motor vehicle safety standard.' "162 Thus, the Court's statement that any rescission requires more justification than a refusal to initiate a rule may only be dictum; its analysis may apply only when the applicable statute equates rescissions with promulgations. Such a restricted view of the State Farm opinion seems unwarranted, however, because the Court states as a general proposition that the "revocation of an existing regulation is substantially different than a failure to act," because revocation is a departure from a settled course of behavior. ${ }^{163}$

Arbitrary and capricious review, however, may not apply generally to rescission of a rule not yet in effect. In rescinding a proposed rule, the agency is not always truly departing from a "settled course of behavior" or a "settled rule" followed in numerous cases that has created strong expectations and changed behavior. Although the NHTSA never finally committed itself to any passive restraint standard as a means to carry out the statutory dictates of the Safety Act, it worked for over a dozen years to develop standards demonstrating a settled course of policy. Earher rescissions of proposed actions should receive less strict review. The government's argument that judicial review of rescissions should be highly deferential is much inore reasonable when the applicable statute is silent concerning the scope of review of rescissions and when the agency has not expended much time and effort in promulgating the rule in the first place.

Along with the scope of review, the Court considered the use of "substantial uncertamty" as a justification for rescission. The Court noted that "just as an agency reasonably may decline to issue a safety

\footnotetext{
Illinois v. NRC, 591 F.2d 12, 14-16 (7th Cir. 1979)(upholding NRC denial of request to institute proceeding and hearing under the Atonic Energy Act of 1954 because NRC's regulatory scheme gives it broad responsibility as to how and when it should proceed); National Black Media Coalition v. FCC, 589 F.2d 578, 581-82 (D.C. Cir. 1978)(upholding FCC's failure to promulgate standards for use in coinparative licensing proceedings because the decision was a policy judgment).

161. State Farm, $103 \mathrm{~S}$. Ct. at 2866.

162. Id. at $2865-66$ (citing 15 U.S.C. \& 1392(b) (1982)).

163. State Farm, $103 \mathrm{~S}$. Ct. at 2866.
} 
standard if it is uncertain about its efficacy, an agency may also revoke a standard on the basis of serious uncertainties if supported by the record and reasonably explained."164 In State Farm, however, the Court rejected the justification because the NHTSA could not make a rational showing that serious uncertamties really did exist because it had not considered the airbag option.

The Court touched on another issue-the necessity of considering alternatives-without resolving it. The majority held that certain alternatives (airbags and nondetachable passive belts) must be considered. Although these alternatives may be rejected later, the NHTSA must demonstrate a reasoned consideration of those options and articulate reasons if it rejects them. ${ }^{165}$ Petitioners in State Farm advanced the argument that Vermont Yankee prevents courts from requiring agencies to consider alternatives because this would be, in essence, dictating to agencies the procedures they must follow. ${ }^{166}$ The Court dismissed this contention because requiring consideration of airbags or belts imposes on the NHTSA no specific procedures that it must follow. ${ }^{167}$

But the Court left unresolved the question of the limits of the lower courts' ability to mandate consideration of further alternatives. The Court conceded that it will not "broadly require an agency to consider all pohicy alternatives in reaching decision" and quoted its statement in Vermont Yankee that a rulemaking "cannot be found wanting simply because the agency failed to include every alternative device and thought conceivable by the mind of man ... regardless of how uncommon or unkown that alternative may have bcen."168 Apparently, agencies need only consider those alternatives that were available at the time of the decision and that were brought forward in the rulemaking proceeding or previously analyzed and found to be worka-

164. Id. at 2871. The Court left for a future case a discussion whether courts can ever require agencies to initiate rulemaking proceedings or even can demand an explanation froin agencies that refuse to act. This may well be one of the inore significant issues of the immediate future as courts recognize the affirmative nature of agencies and citizens attempt to make agencies initiate rulemaking, especially in an era of deregulation and under an administration that is hesitant to encourage more government regulatory action. See Stewart \& Sunstein, Public Programs and Private Rights, 95 HARv. L. REv. 1195, 1209-47 (1982); Note, Judicial Review of Administrative Inaction, 83 COLUM. L. REv. 627, 628-45 (1983); see also Rockford League of Women Voters v. NRC, 679 F.2d 1218, 1222 (7th Cir. 1982)(upholding refusal of NRC to institute a proceeding to revoke a construction permit for a nuclear plant on ground that courts should exercise extremely limited scope of review of agency inaction because how an agency chooses to use its resources "calls for managerial judgment"). See generally Natural Resources Defense Council v. SEC, 606 F.2d 1031, 1053-57 (D.C. Cir. 1979).

165. State Farm, 103 S. Ct. at 2868-74.

166. Petition for Writ of Certiorari by MVMA at 22-23, State Farm, 103 S. Ct. 2856 (1983).

167. State Farm, $103 \mathrm{~S}$. Ct. at 2870-71.

168. Id. at 2871 (quoting Vermont Yankee, 435 U.S. at 551). 
ble and effective. But what of "obvious" alternatives that the agency has not considered or at least discussed? Allowing a court to require the agency to consider alternatives not previously brought forward would risk delay of agency action and would place courts in the role of the expert policyinaker that agencies were designed to fill.

The final question that State Farm raises, which is related to the issue discussed earlier of private interest administrative politics and regulatory capture, ${ }^{169}$ is the extent to which the Executive and electoral politics can influence agency decisionmaking. It was not so much "pressure" from the automobile manufacturers that led to the rescission of the passive restraint standard as it was the "suggestions" and directives from the White House relating to President Reagan's goal of eliminating "unnecessary" and wasteful regulations that had an adverse economic effect on American industry. Should the courts defer to agency decisions "encouraged" by changes in administration?

The dissenters in State Farm would be inore likely to accept such politically motivated decisions. They not only recognize the role of executive oversight but applaud the idea that politics in the broader sense may be a determining factor in an agency's decision to rescind a regulation advanced by a previous adınimistration: "A change in administration brought about by the people casting their votes is a perfectly reasonable basis for an executive agency's reappraisal of the costs and benefits of its programs and regulations." 170

The majority did not deal exphicitly with the issue of executive control, but vaguely worded congressional authorizations to agencies demand that Presidents exercise soine executive control of agency discretion. It is difficult for Congress to react to changes in the economic or technical situation by rewriting legislation, whereas the President does have the ability to respond. ${ }^{171}$ In addition, the legitimacy of poli-

169. See supra text accompanying notes 153-58.

170. State Farm, 103 S. Ct. at 2875 (Rehnquist, J., dissenting).

The agency's changed view of the standard seems to be related to the election of a new President of a different political party. It is readily apparent that the responsible members of one administration may consider publie resistance and uncertainties to be more important than do their counterparts in a previous administration. . . As long as the agency remains witlin the bounds establislred by Congress, it is entitled to assess administrative records and evaluate priorities in light of the plilosophy of the admistration.

Id. at 2875 (Rehnquist, J., dissenting). "Of course, a new administration may not choose not to enforce laws of which it does not approve, or to ignore statutory standards in carrying out its

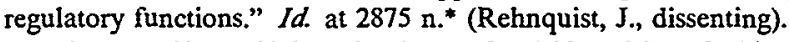

171. E.g., Sierra Club v. Costle, 657 F.2d 298, 406 (D.C. Cir. 1981)(footnotes omitted), rev'd, 103 S. Ct. 3274 (1983):

The authority of the President to control and supervise executive policymaking is derived from the Constitution; the desirability of such control is demonstrable from the practical realities of administrative rulemaking. Regulations such as those involved here demand a careful weighing of cost, environmental, and energy considerations. They also 
cymaking by unelected administrators depends upon the control of those administrators by the public, acting through the only nationally elected official-the President. In State Farm, however, the factor of executive directives to the NHTSA apparently carried little weight in the majority's consideration.

\section{CONCLUSION}

State Farm is an important case that suggests some answers and leaves some questions. It is the Supreme Court's first opinion that considers the scope of review for a rescission of a rule. Because the enabling statute in State Farm dealt with the issue, it remains unclear whether rescissions of standards lacking a "settled course of behavior" are subject to the saine scope of review. Also unclear is the extent to which the federal courts may demand that agencies take into account alternatives apparent to the courts and whether failure to do so will always constitute a lack of reasoned decisionmaking. The Court left for another case the major issue of whether the public and the courts can ever force agencies to initiate rulemaking proceedings.

State Farm does answer several questions. It warns the federal courts not to alter the intensity of judicial review based on a readimg of congressional commitment to a policy if that reading is derived from unenacted legislative "intent." It warns the agencies that, at least where public safety is concerned, they may not consider regulated parties' well-being more important than the public interest. Most importantly, the decision in State Farm resurrects Overton Park's directive that courts must engage in a "thorough, probing, in-depth review" of the agency decisionmaking process. The Supreme Court informs us that Vermont Yankee stands as a procedural and not a substantive limitation and that "hard look" review is legitimate.

Neil D. McFeeley

have broad implications for national economic policy. Our form of government simply could not function effectively or rationally if key executive policymakers were isolated from each other and from the Chief Executive. Single mission agencies do not always have the answers to complex regulatory problems. 